\title{
Role of MMP-7 in the formation of peritoneal dissemination in gastric cancer
}

\author{
Yutaka Yonemura ${ }^{1}$, Yoshio Endou ${ }^{2}$, Hideto Fujita ${ }^{1}$, Sachio Fushida $^{1}$, Etsurou Bandou ${ }^{1}$, Keizou Taniguchi ${ }^{1}$, \\ Kouichi Miwa ${ }^{1}$, Kazuo SugiYama ${ }^{3}$, and Takuma Sasaki ${ }^{2}$ \\ ${ }^{1}$ Second Department of Surgery, School of Medicine, Kanazawa University, 13-1 Takara-machi, Kanazawa 920-8641, Japan \\ ${ }^{2}$ Department of Experimental Therapeutics, Cancer Research Institute, Kanazawa University, 13-1 Takara-machi, Kanazawa 920-8641, Japan \\ ${ }^{3}$ Virology Division, National Cancer Center Research Institute, 5-1-1 Tsukiji, Chuo-ku, Tokyo 104-0045, Japan
}

\begin{abstract}
Background. Matrix metalloproteinase-7 (MMP-7) is an important matrix-degrading enzyme that has a large role in the invasion and metastasis of cancer. To discover the mechanism of the formation of peritoneal dissemination in gastric cancer, we studied the mRNA and protein expression of MMP-7 in primary gastric cancers and peritoneal dissemination.

Methods. MMP-7 expression in primary gastric cancers (136 patients) was studied by immunohistochemistry and reverse transcription-polymerase chain reaction (RT-PCR), and the results were compared with chinicopathological parameters.

Results. MMP-7 mRNA was expressed in 28 (53\%) of 53 primary gastric cancers, but not in normal gastric mucosa, fibroblasts, or mesothelial cells. An immunohistochemical method demonstrated that MMP-7 immunoreactivity was found on the cell membrane and cytoplasm of cancer cells. Among 136 primary tumors, 70 (53\%) tumors overexpressed MMP-7, and MMP-7 tissue status had significant positive correlation with serosal involvement, lymph node metastasis, poor differentiation of cancer, and peritoneal dissemination. Patients with MMP-7-positive tumor had significantly poorer survival and more frequently died of peritoneal recurrence than did those with MMP-7-negative tumors. All 6 examined peritoneal disseminations expressed MMP-7 mRNA, and 13 of 14 peritoneal disseminations showed immunoreactivity to anti-human MMP-7 monoclonal antibody. Logistic regression analysis showed that MMP-7 immunohistological status was an independent risk factor for peritoneal dissemination, and patients with MMP-7 mRNA-positive tumors had a 9.9-fold higher relative risk for peritoneal metastasis.

Conclusion. These results strongly suggest that MMP-7 may have a large role in the formation of peritoneal dissemination in gastric cancer, and that clonal selection of cancer cells with MMP-7 overexpression may occur during the invasion of intraperitoneal free cancer cells from the peritoneal surface into the subperitoneal tissue. MMP-7 tissue status in the primary tumor may be a good indicator of peritoneal dissemination.
\end{abstract}

Offprint requests to: Y. Yonemura

Received: February 24, 2000 / Accepted: May 16, 2000
Key words MMP-7 - Gastric cancer · Peritoneal carcinomatosis $\cdot$ Peritoneal dissemination

\section{Introduction}

Peritoneal dissemination is a leading cause of death from gastrointestinal cancer; there is no effective treatment for peritoneal carcinomatosis. About $40 \%$ of patients with advanced gastric cancer died of this type of metastasis [1]. Considerable efforts have been made to prevent peritoneal recurrence, but large randomized trials have failed to demonstrate the efficacy of prevention. One of the major reasons for the pessimistic results of clinical trials lies in the poor understanding of the mechanisms of the formation of peritoneal dissemination.

At present, cancer metastasis is considered to be formed through multi-step processes by the activation of metastasis-related genes [2]. Peritoneal dissemination is also formed through several steps [2]: (1) detachment of cancer cells from the primary tumor, (2) attachment to distant peritoneum, (3) invasion into subperitoneal space, and (4) proliferation with vascular neogenesis. The origin of peritoneal carcinoamtosis in gastric cancer is considered to be intraperitoneal free cancer cells, exfoliated from the serosal surface of the primary tumor. In gastric cancer, intraperitoneal free cancer cells can be detected by peritoneal wash cytology in $40 \%-60 \%$ of patients with stage III or IV disease $[4,5]$.

Free cancer cells attach to the distant peritoneum or migrate into the submesothelial lymphatic spaces (called milky spots) in the greater omentum or mesentery, and stomata in the diaphragm. In the process of attachment of free cancer cells to the peritoneum [3], we have already clarified the important roles of VLA-2, VLA-3 and several cytokines, such as 
interleukin (IL)-6, IL-8, and hepatocyte growth factor (HGF) [6,7]. Intraperitoneal free cancer cells attach to the subperitoneal basement membrane by expressing VLA-2 or VLA-3 on the cell membrane, because VLA2 and VLA-3 are receptors for the constituents of submesothelial basement membrane, like laminin and collagen.

However, the identity of the molecules that are associated with the process of cancer cell invasion into the submesothelial tissue remains unclear. Recent advances in molecular biology showed that matrix-degrading enzymes, including matrix metalloproteinases (MMPs) and serine proteases, were involved in tumor invasion.

Regarding MMPs, more than 17 subfamilies have been identified. Among them, MMP-7 is known to be expressed by the glandular epithelium [8] and by cancer cells $[9,10]$, and other metalloproteinases are expressed not only by the stromal component [10] but also by the cancer cells. MMP-7 can degrade a wide range of substrates, including proteoglycans, fibronectin, gelatin, and casein. MMP-7 has a stronger enzymatic activity than any other members of the MMP family [11,12]. In addition, MMP-7 activates other proMMPs such as proMMP-1, $-3,-8$, and $-9[13,14]$. Consequently, MMP7 can cleave almost all kinds of stromal elements. ProMMP-7 is activated by 4 -aminophenylmercuric acetate (APMA), trypsin, and MMP-3 following the stepwise mechanisms proposed for other proMMPs [15].

We report here the close relationship between MMP7 expression and peritoneal metastasis in gastric cancer. To the best of our knowledge, there has been no article published previously on this relationship.

\section{Subjects, materials, and methods}

\section{Cell lines}

Seven gastric cancer cell lines (KATO-III, KKLS, MKN-45, MKN-28, TMK-1, NKPS, and NUGC-3) and a cell line of fibroblasts (KMST-6) were cultured in RPMI-1640 medium with $10 \%$ fetal calf serum (GIBCO BRL, Gaithersburg, MD, USA).

\section{Patients and tumor samples}

One hundred and thirty-six patients with primary gastric cancer diagnosed and treated at the Second Department of Surgery, Kanazawa University Hospital, between 1990 and 1997, were entered into the study. All the patients underwent gastrectomy with lymph node dissection. Immediately after resection of the primary tumor, samples, about 5-mm in diameter, were taken from 53 primary tumors, each adjacent normal mucosa, and 6 metastatic tumors on the peritoneal surface, and these samples were stored at $-80^{\circ} \mathrm{C}$. In addition, small pieces of tissue, about 5- to $8-\mathrm{mm}$ in diameter, were sampled from the 136 primary tumors and 14 peritoneal metastases, fixed in acetone at $-20^{\circ} \mathrm{C}$ overnight, and prepared to make paraffin-embedded blocks by the AMeX method [17]. All the resected primary tumors and regional lymph nodes were histologically examined by H\&E staining, according to the general rules of the Japanese classification of gastric cancer [16].

\section{Antibodies and immunohistochemistry}

Immunohistochemistry was done as described previously [6,7]. Deparaffinized sections were incubated overnight at $4{ }^{\circ} \mathrm{C}$ with anti-MMP-7 antibody (Fuji Pharmaceutical, Takaoka, Japan) diluted 1:100 in phosphate-buffered saline (PBS). This monoclonal antibody was developed using a synthetic peptide corresponding to the amino acid sequence of the COOH-terminal peptide of human MMP-7 (residues 253-267) [9]. Next, the slides were incubated with biotinylated goat antimouse IgG for $20 \mathrm{~min}$ (LSAB kit; Dako, Copenhagen, Denmark) and then with premixed Avidin-Biotin complex (ABC) (Dako) reagent for 20 min. Immunostaining was done with diaminobenzidine (Dako) solution with hydrogen peroxide for $1 \mathrm{~min}$. Negative controls were done in all cases by omitting the first antibody. Only cases in which at least $20 \%$ of the tumor cells were immunoreactive were scored as positive.

\section{Reverse transcription-polymerase chain reaction $(R T-P C R)$}

RT-PCR analysis was done according to $\mathrm{Ng}$ et al. [19] and Conboy et al. [20], modifications. With Briefly, total RNAs were extracted from primary gastric cancer, normal gastric mucosa, the cell line of fibroblasts (KMST6), human mesothelial cells, and the seven gastric cancer cell lines, using Isogen (Nippon Gene, Tokyo, Japan) [18]. Human mesothelial cells were isolated from human greater omentum, as we have already reported [21]. The prepared RNA was mixed with oligo-dT primer and was reverse-transcribed with avian mylo cytic leukemia virus (AMV) reverse transcriptase (Life Sciences, St. Petersburg, Fl, USA), followed by PCR amplification (Perkin-Elmer Cetus, Norwalk, CT, USA) with specific primers (Table 1). PCR amplifcation was done for $1.5 \mathrm{~min}$ at $94^{\circ} \mathrm{C}, 2 \mathrm{~min}$ at $48^{\circ} \mathrm{C}$, and $2 \mathrm{~min}$ at $72^{\circ} \mathrm{C}$ for three cycles, then with 25 cycles of $40 \mathrm{~s}$ at $94^{\circ} \mathrm{C}$, $1.5 \mathrm{~min}$ at $48^{\circ} \mathrm{C}$, and $1.3 \mathrm{~min}$ at $72^{\circ} \mathrm{C}$. The PCR products were electrophoresed on $2 \%$ agarose gels and transferred to a nylon membrane filter. The transferred products were hybridized overnight to a ${ }^{32} \mathrm{P}$-end-labeled probe specific for the target cDNA fragment (Table 1). 
Table 1. List of primers and probes used

\begin{tabular}{|c|c|c|c|}
\hline & DNA fragment & DNA sequences & \\
\hline \multirow[t]{3}{*}{$M M P-7$} & \multirow[t]{3}{*}{418 bp } & 5'-ACTTTAAACTCCCGCGTCATA-3' & Sense \\
\hline & & 5'-TGCCAGATGTTGCAGAATACT-3' & Antisense \\
\hline & & 5'-CCAATCATGATGTCAGCAGTT-3' & Probe \\
\hline \multirow[t]{3}{*}{$\beta$-Actin } & \multirow[t]{3}{*}{592 bp } & 5'-TTCAAGGTAGTTTCGTGGAT-3' & Sense \\
\hline & & 5'-GAAAATCTGGCACCACACCTT-3' & Antisense \\
\hline & & 5'-ACTGACTACCTCATGAAGAT-3' & Probe \\
\hline \multirow[t]{3}{*}{$T F R$} & \multirow[t]{3}{*}{$415 \mathrm{bp}$} & 5'-ACAGACTCTACATGTAGGAT-3' & Sense \\
\hline & & 5'-AAACCTTGAAGTTGCTGGTA-3' & Antisense \\
\hline & & 5'-ТАТСССТСТАGCCATTCAGT-3' & Probe \\
\hline
\end{tabular}

MMP-7, Matrix metalloproteinase 7; TFR, transferrin receptor

The autoradiogram was exposed for $4-5 \mathrm{~h}$ with two intensifying screens at $-80^{\circ} \mathrm{C}$. Specific primers for the $M M P$-7 gene, $\beta$-actin gene, and transferrin receptor $(T F R)$ gene are shown in Table $1[19,20]$.

\section{Data presentation and statistical analysis}

All statistical calculations were done with SPSS statistical software (Chicago, IL, USA). Values are shown as means plus or minus SD. The $\chi^{2}$ test and Student's $t$-test for unpaired samples were used to analyze data. The outcomes of the different groups of patients were compared by the generalized Wilcoxon test. To clarify MMP-7 tissue status as a predictor of peritoneal dissemination, we did logistic regression analysis.

\section{Results}

MMP-7 expression in gastric cancer cell lines, fibroblasts, and primary gastric cancer

MMP-7 mRNA was expressed in MKN-45, NUGC-3, KATO-III, NKPS, and MKN-28, but TMK-1 and KKLS did not express MMP-7 mRNA (Fig. 1). KMST6, which is an immortalized cell line of fibroblasts, did not express MMP-7 mRNA (Fig. 1).

In the clinical specimens, MMP-7 mRNA was mainly expressed in primary tumors (Fig. 2). MMP-7 mRNA was detected in $28(53 \%)$ of 53 primary gastric cancers, but not in normal gastric mucosa.

Tissue localization and expression of MMP-7 in gastric cancer and peritoneal dissemination

As shown in Fig. 3, immunohistochemical study showed MMP-7 expression on the cytoplasm or cell membrane of gastric cancers, but not in the normal gastric mucosa or stromal tissue. MMP-7 immunoreactivity was expressed in $70(51 \%)$ of the 136 primary gastric cancers.

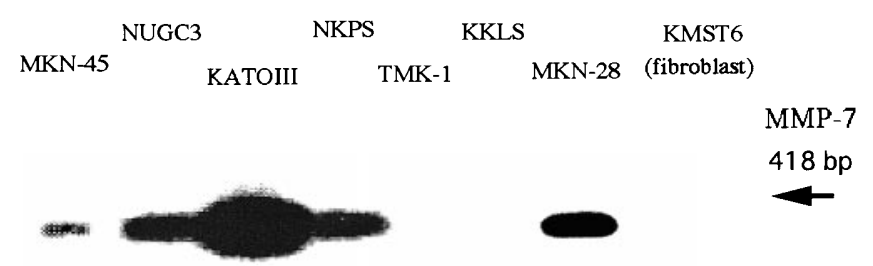

Fig. 1. Matrix metalloproteinase-7 (MMP-7) mRNA expression in gastric cancer cell lines and a fibroblast cell line (KMST6)

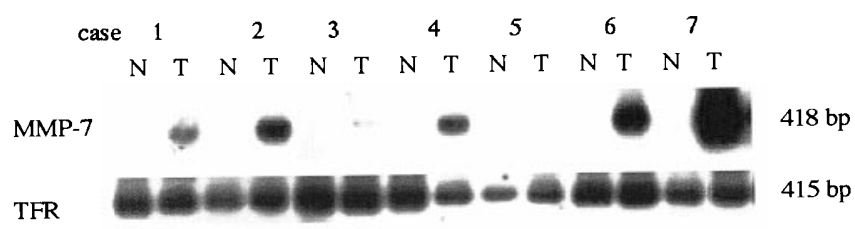

Fig. 2. MMP-7 mRNA expression in primary gastric cancer and adjacent normal mucosa. $T$, Tumor; $N$, normal counterpart; $T F R$, transferrin receptor

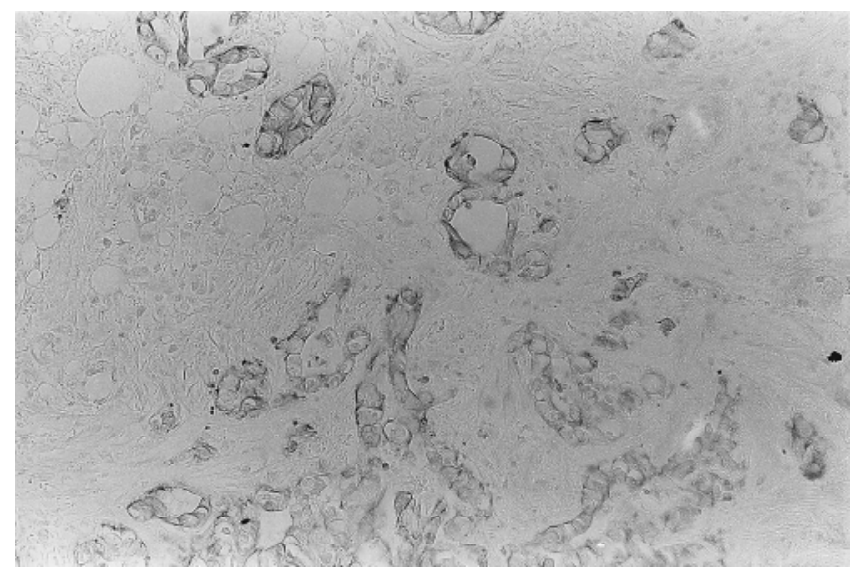

Fig. 3. MMP-7 expression in primary gastric cancer (immunohistochemistry). $\times 200$ 
Relationship between clinicopathological parameters and MMP-7 expression

MMP-7 mRNA expression in primary tumors had a significant relationship with positive serosal involvement (Table 2). Peritoneal dissemination was found in $2(8 \%)$ of 25 MMP-7 mRNA-negative tumors, but 9 (32\%) of 28 MMP-7 mRNA-positive tumors had peritoneal dissemination $(P<0.05)$. Tissue status of MMP-7 protein expression was significantly associated with lymph node metastasis, serosal involvement, peritoneal dissemination, and lymphatic invasion (Table 3). In addition, MMP-7 immunoreactivity was expressed in a significantly higher proportion of poorly differentiated adenocarcinomas compared with that in differentiated adenocarcinomas (Table 3). Infiltrating type of cancer tended to overexpress MMP-7 more than did localized tumors, and the proportion of MMP-7 overexpression in early gastric cancer $(21 \% ; 7 / 33)$ was significantly lower than that in advanced gastric cancer $(61 \% ; 63 /$ 103) $(P<0.05)$.

Survival of patients in terms of MMP-7 tissue status, and recurrence mode after operation

As shown in Fig. 4, the survival rate was lower for patients with gastric cancer with positive MMP-7 status than for those with MMP-7-negative status.
Recurrence developed in 50 patients. Of 70 patients with tumors showing positive MMP-7 immunoreactivity, $25(36 \%)$ developed peritoneal recurrence (Table 4). This was significantly higher than the proportion $(8 \% ; 5 / 66)$ in patients with MMP-7-negative tumors.

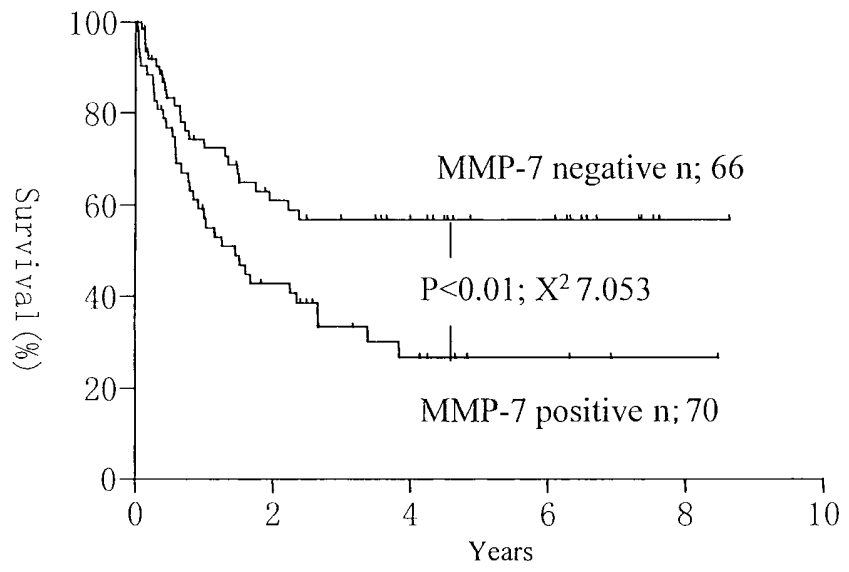

Fig. 4. Survival of patients with gastric cancer according to MMP-7 tissue status. In terms of immunohistochemical MMP7 tissue status, patients with MMP-7-positive tumor survived significantly longer than did those with an MMP-7-negative one

Table 2. Relationship between clinicopathologic parameters and MMP-7 mRNA expression in primary gastric cancer

\begin{tabular}{|c|c|c|c|}
\hline & \multicolumn{2}{|c|}{$\begin{array}{l}\text { MMP-7 mRNA expression } \\
\text { in primary tumors }\end{array}$} & \multirow[b]{2}{*}{ Significance } \\
\hline & Positive & Negative & \\
\hline \multicolumn{4}{|l|}{ Liver metastasis } \\
\hline Positive & $2(7 \%)$ & $0(0 \%)$ & \multirow[t]{2}{*}{ NS } \\
\hline Negative & $26(93 \%)$ & $25(100 \%)$ & \\
\hline \multicolumn{4}{|l|}{ Peritoneal dissemination } \\
\hline Positive & $9(32 \%)$ & $2(8 \%)$ & \multirow[t]{2}{*}{$P<0.05$} \\
\hline Negative & $19(68 \%)$ & $23(92 \%)$ & \\
\hline \multicolumn{4}{|l|}{ Serosal invasion } \\
\hline Positive & $22(79 \%)$ & $10(40 \%)$ & \multirow[t]{2}{*}{$P<0.05$} \\
\hline Negative & $6(21 \%)$ & $15(60 \%)$ & \\
\hline \multicolumn{4}{|l|}{ Lymph node metastasis } \\
\hline Positive & $21(75 \%)$ & $15(60 \%)$ & \multirow[t]{2}{*}{ NS } \\
\hline Negative & $7(25 \%)$ & $10(40 \%)$ & \\
\hline \multicolumn{4}{|l|}{ Histologic type } \\
\hline Differentiated type & $11(39 \%)$ & $12(48 \%)$ & \multirow[t]{2}{*}{ NS } \\
\hline Poorly differentiated type & $17(61 \%)$ & $13(52 \%)$ & \\
\hline \multicolumn{4}{|l|}{ Lymphatic invasion } \\
\hline Positive & $16(57 \%)$ & $14(56 \%)$ & \multirow[t]{2}{*}{ NS } \\
\hline Negative & $12(43 \%)$ & $11(44 \%)$ & \\
\hline \multicolumn{4}{|l|}{ Venous invasion } \\
\hline Positive & $15(54 \%)$ & $13(52 \%)$ & \multirow[t]{2}{*}{ NS } \\
\hline Negative & $13(46 \%)$ & $12(48 \%)$ & \\
\hline Total & 28 & 25 & \\
\hline
\end{tabular}

NS, Not significant 
Table 3. Correlations between MMP-7 immunoreactivity in primary tumors and clinicopathologic parameters

\begin{tabular}{|c|c|c|c|}
\hline & \multicolumn{2}{|c|}{$\begin{array}{l}\text { MMP-7 immunoreactivity } \\
\text { in primary tumor }\end{array}$} & \multirow[b]{2}{*}{ Significance } \\
\hline & Positive & Negative & \\
\hline \multicolumn{4}{|l|}{ Liver metastasis } \\
\hline Positive & $3(4 \%)$ & $8(12 \%)$ & NS \\
\hline Negative & $67(96 \%)$ & $58(88 \%)$ & \\
\hline \multicolumn{4}{|l|}{ Peritoneal dissemination } \\
\hline Positive & $27(39 \%)$ & $5(8 \%)$ & $P<0.01$ \\
\hline Negative & $43(61 \%)$ & $61(92 \%)$ & \\
\hline \multicolumn{4}{|l|}{ Serosal involvement } \\
\hline Positive & $63(90 \%)$ & $36(55 \%)$ & $P<0.01$ \\
\hline Negative & $7(10 \%)$ & $30(45 \%)$ & \\
\hline \multicolumn{4}{|l|}{ Lymph node metastasis } \\
\hline Positive & $51(73 \%)$ & $33(50 \%)$ & $P<0.05$ \\
\hline Negative & $19(27 \%)$ & $33(50 \%)$ & \\
\hline \multicolumn{4}{|l|}{ Histologic type } \\
\hline Differentiated type & $45(64 \%)$ & $28(42 \%)$ & $P<0.05$ \\
\hline Poorly differentiated type & $25(36 \%)$ & $38(58 \%)$ & \\
\hline \multicolumn{4}{|l|}{ Lymphatic invasion } \\
\hline Positive & $54(77 \%)$ & $38(58 \%)$ & $P<0.05$ \\
\hline Negative & $16(23 \%)$ & $28(42 \%)$ & \\
\hline \multicolumn{4}{|l|}{ Venous invasion } \\
\hline Positive & $48(69 \%)$ & $36(55 \%)$ & NS \\
\hline Negative & $22(31 \%)$ & $30(45 \%)$ & \\
\hline \multicolumn{4}{|l|}{ Patterns of growth } \\
\hline Localized & $5(7 \%)$ & $11(17 \%)$ & \\
\hline Intermediate & $22(32 \%)$ & $34(51 \%)$ & $P<0.05$ \\
\hline Infiltrating & $43(61 \%)$ & $21(32 \%)$ & \\
\hline \multicolumn{4}{|l|}{ Macroscopic type } \\
\hline Early cancers & $7(10 \%)$ & $26(39 \%)$ & \\
\hline Borrmann type 1,2 & $17(24 \%)$ & $12(19 \%)$ & $P<0.05$ \\
\hline Borrmann type 3,4 & $46(66 \%)$ & $28(42 \%)$ & \\
\hline Total & 70 & 66 & \\
\hline
\end{tabular}

Table 4. Recurrence pattern and MMP-7 immunoreactivity expression in primary tumors

\begin{tabular}{lccc}
\hline & \multicolumn{2}{c}{$\begin{array}{c}\text { MMP-7 immunoreactivity } \\
\text { in primary tumor }\end{array}$} & \\
\cline { 2 - 3 } Recurrence mode & Negative & Positive & \\
\hline Peritoneum & $5(8 \%)$ & $25(36 \%)$ & $P<0.01$ \\
Liver & $8(12 \%)$ & $4(6 \%)$ & \\
Lymph node & $5(8 \%)$ & $8(11 \%)$ & \\
Bone & $2(3 \%)$ & $1(1 \%)$ & \\
Free of recurrence & $46(70 \%)$ & $32(46 \%)$ & \\
Total & 66 & 70 &
\end{tabular}

\section{MMP-7 expression in peritoneal dissemination}

MMP-7 immunoreactivity was found in specimens from peritoneal dissemination (Fig. 5), with a positive incidence of $93 \%(13 / 14)$. One tumor that was negative for MMP-7 immunoreactivity was pseudomyxoma peritonei from gastric cancer.

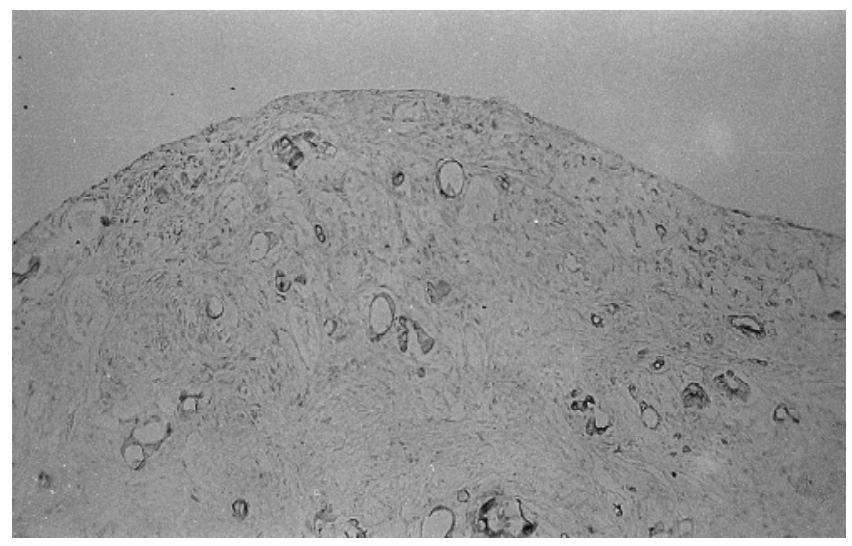

Fig. 5. MMP-7 expression in peritoneal dissemination (immunohistochemistry). $\times 100$ 
Figure 6 shows the MMP-7 mRNA expression in peritoneal disseminations. Although mesothelial cells did not express MMP-7, bands compatible with MMP-7 mRNA were found in all the samples obtained from peritoneal disseminations.

We did a logistic regression analysis to identify the independent risk factors for peritoneal dissemination. As shown in Table 5, MMP-7 tissue status emerged as an independent risk factor for peritoneal dissemination.

\section{Discussion}

As shown in the logistic regression analysis, MMP-7 tissue status in gastric cancer was an independent

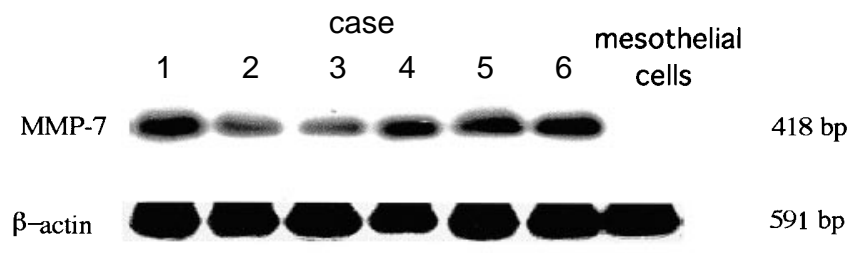

Fig. 6. MMP-7 mRNA expression in peritoneal dissemination and mesothelial cells (reverse transcription-polynerase chain reaction method) predictor of peritoneal dissemination. Accordingly, this study clearly demonstrates a close relationship between peritoneal dissemination and MMP-7 expression in gastric cancer. Some investigators have reported that matrix-digesting enzymes other than MMP-7, such as urokinase type plasminogen activator receptor (UPAR), urokinase type plasminogen activator (UPA), and membrane type (MT1)-MMP [22,23], are also involved in the progression of gastric cancer. Among these matrixdegrading enzymes, MMP-7 is unique, in that it is expressed by tumor cells themselves rather than by the stromal cells [8]. By the in-situ hybridization technique, Yamashita et al. [24] reported that MMP-7 mRNA signals were exclusively found in the cytoplasm of gastric cancer cells. In this present study, KMST-6, a fibroblast cell line, and normal gastric mucosa and mesothelial cells did not express MMP-7 mRNA.

These results indicate that MMP-7 is mainly produced by gastric cancer cells. Accordingly, MMP-7producing cancer cells have a high matrix-degrading activity in the pericellular space, making them highly invasive.

In the clinical specimens, primary tumros with MMP7 overexpression were significantly more likely to show positive serosal involvement, lymph node metastasis, and peritoneal dissemination than did the specimens

Table 5. Multivariate analysis with respect to peritoneal metastasis in gastric cancer (logistic regression analysis)

\begin{tabular}{|c|c|c|c|c|}
\hline \multirow[b]{2}{*}{ Clinicopathologic factors } & \multicolumn{4}{|c|}{ Multivariate analysis } \\
\hline & $\chi^{2}$ & $P$ value & Risk ratio & $95 \%$ CI \\
\hline Macroscopic type & & & & \\
\hline $\begin{array}{l}\text { Early gastric cancer } \\
\text { Advanced gastric cancer }\end{array}$ & 1.689 & 0.194 & 2.201 & $0.431-5.395$ \\
\hline Lymph node metastasis & & & & \\
\hline $\begin{array}{l}\text { Negative } \\
\text { Positive }\end{array}$ & 5.127 & 0.023 & 5.375 & $1.331-18.113$ \\
\hline Histologic type & & & & \\
\hline $\begin{array}{l}\text { Differentiated type } \\
\text { Poorly differentiated type }\end{array}$ & 0.572 & 0.499 & 1.475 & $0.538-4.041$ \\
\hline $\begin{array}{l}\text { Serosal invasion } \\
\text { Negative } \\
\text { Positive }\end{array}$ & 3.869 & 0.049 & 3.65 & $1.012-11.498$ \\
\hline $\begin{array}{l}\text { Infiltrating pattern } \\
\text { Localized } \\
\text { Infiltrating }\end{array}$ & 0.426 & 0.514 & 1.524 & $0.431-5.395$ \\
\hline $\begin{array}{l}\text { Vessel invasion } \\
\text { Negative } \\
\text { Positive }\end{array}$ & 0.324 & 0.569 & 1.715 & $0.268-10.999$ \\
\hline $\begin{array}{l}\text { Lymphatic invasion } \\
\text { Negative } \\
\text { Positive }\end{array}$ & 0.397 & 0.529 & 1.489 & $0.053-4.509$ \\
\hline $\begin{array}{l}\text { MMP-7 immunohistological status } \\
\text { Negative } \\
\text { Positive }\end{array}$ & 7.852 & 0.005 & 9.921 & $1.624-14.996$ \\
\hline
\end{tabular}

CI, Confidence interal 
with MMP-7 negative tumors. Furthermore, MMP-7 overexpression in poorly differentiated adenocarcinoma and the macroscopically infiltrating type was significantly more frequent than that in differentiated adenocarcinoma and the localized type.

The phenotypes of poorly differentiated adenocarcinoma or macroscopically infiltrating tumor are well known as tumors that tend to develop peritoneal recurrence [1]. Poorly differentiated adenocarcinomas tend to grow in an infiltrating type of tumor growth pattern and to exfoliate easily from the serosal surface, because of the loss of cell-to-cell adhesion due to an abnormality of the E-cadherin gene [25].

Accordingly, simultaneous expression of MMP-7 and down-regulation of E-cadherin expression may render gastric cancer cells more invasive and metastatic. As a result, these cancer cells are prone to exfoliate from the serosal surface and to become intraperitoneal free cancer cells.

We previously reported a significant role of integrins $\alpha 2$ and $\alpha 3$ in the attachment of intraperitoneal free cancer cells on the peritoneal surface [6]. After such attachment, cancer cells must invade the subperitoneal tissue and move to the perivascular space to get enough nutrition and oxygen from submesothelial blood capillaries [26]. If cancer cells have no ability to invade the subperitoneal tissue, almost all the cells may die off on the peritoneal surface. To accomplish the invasion process smoothly, the production of matrix-degrading enzymes in the pericellular space of the cancer cells is essential. In the early stage of peritoneal dissemination, however, inflammatory reactions may be rare, and cancer cells cannot invade the subperitoneal tissue by using matrix-degrading enzymes, such as MMP-2 and MMP9 , which are produced by fibroblasts or inflammatory cells.

Accordingly, MMP-7, which is exclusively produced by the cancer cells themselves, must have an important role in the completion of this process. Interestingly, this present study demonstrated that MMP-7 mRNA was detected in all specimens of peritoneal dissemination. In addition, logistic regression analysis demonstrated that MMP-7 tissue status was an independent risk factor for peritoneal dissemination.

These results suggest that the clonal selection of cancer cells with MMP-7 overexpression may occur during the invasion of intraperitoneal free cancer cells from the peritoneal surface into the subperitoneal tissue.

Furthermore, these results suggest that MMP-7 has a large role in the establishment of peritoneal dissemination, and that MMP-7 is a reliable predictor of peritoneal recurrence after curative resection of gastric cancer. Accordingly, MMP-7 may be a highly suitable molecular target for gene therapy for peritoneal carcinomatosis. We are now trying to treat experimental peritoneal carcinomatosis with antisense oligonucleotides against MMP-7 mRNA.

\section{References}

1. Nakajima T, Harashima S, Hirata M, Kajitani T. Prognostic and therapeutic values of peritoneal cytology in gastric cancer. Acta Cytol 1978;22:225-9.

2. Liotta LA. Tumor invasion and metastasis: role of the extracellular matrix. Cancer Res 1986;46:1-7.

3. Yonemura Y. Hyperthermo-chemotherapy for the treatment of peritoneal carcinomatosis. In: Yoneumura Y, editor. Peritoneal dissemination. Molecular mechanisms and the latest therapy. Kanazawa: Maeda Shoten; 1998. p. 237-59.

4. Iitsuka Y, Kaneshima S, Tanida O, Takeuchi T, Koga S. Intraperitoneal free cancer cells and their viability in gastric cancer. Cancer 1979;44:1476-80.

5. Koga S, Kaibara N, Iitsuka Y, Kudo H, Kimura A, Hiraoka H. Prognostic significance of intraperitoneal free cancer cells in gastric cancer patients. J Cancer Res Clin Oncol 1984;108:236-8.

6. Yonemura Y, Endou Y, Yamaguchi T, Nojima N, Kawamura T, Fujimura T, et al. Roles of VLA-2 and VLA-3 on the formation of peritoneal dissemination in gastric cancer. Int J Oncol 1996;8:92531.

7. Yonemura Y, Endou Y, Yamaguchi T, Fujimura T, Obata T, Kawamura T, et al. Mechanisms of the formation of the peritoneal dissemination in gastric cancer. Int J Oncol 1996;8:795-802.

8. Matrisian, LM. The matrix-degrading metalloproteinases. Bioessays 1992;14:455-63.

9. Iami K, Yokohama Y, Nakanishi I, Ohuchi E, Fujii Y, Nakai N, Okada Y. Matrix metalloproteinase 7 (matrilysis) from human rectal carcinoma cells. J Biol Chem 1995;270:6691-7.

10. McDonnell S, Narve M, Coffey RJ, Matrisian LM. Expression and localization of the matrix metalloproteinase pump-l (MMP-7) in human gastric and colon carcinomas. Mol Carcinogenesis 1991; 4:521-33.

11. Murphy G, Cockett MI, Ward RV, Docherty AJP. Matrix metalloporteinase degradation of elastin, type IV collagen and proteoglycan. Biochem J 1991;277:277-9.

12. Miyazaki K, Hattori Y, Umenishi F, Yasumitsu H, Umeda, M. Purification of extracellular matrix-degrading metalloproteinase, matrin (PUMP-1), secreted from rectal carcinoma cell line. Cancer Res 1990;50:7758-64.

13. Murphy G, Cockett MI, Slephens PE, Smith BJ, Docherty AJP. Stromelysin is an activator of procollagenase. Biochem J 1987; 248:265-8.

14. Suzuki K, Enghild JJ, Morodomi T, Salvesen G, Nagase, H. Mechanisms of activation of tissue procollagenase by matrix metalloproteinase 3 (stromelysin). Biochem J 1990;29:10261-70.

15. Crabbe T, Willenbrock F, Eaton D, Hynds P, Carne AF, Murphy G, Dockerty AJP. Biochemical characterization of matrilysin. Activation conforms to the stepwise mechanisms proposed for other matrix metalloproteinases. Biochem J 1992;31:8500-7.

16. Japanese Research Society for Gastric Cancer. Japanese classification of gastric cancer. Tokyo: Kanehara 1993.

17. Sato Y, Mukai K, watanabe S, Goto M, Shimosato Y. The AMeX method: a simplified technique of tissue processing and paraffin embedding with improved preservation of antigens for immunostaining. Am J Pathol 1986;125:431-5.

18. Chomczybsky P, Sacchi N. Single-step method of RNA isolation by acid guanidinium thiocyanate-phenol-chloroform extraction. Anal Biochem 1987;162:156-9.

19. Ng S, Gunning P, Eddy R, Ponte P, Leavitt J, Shows T, Kedes L. Evolution of the functional human $\beta$-actin gene and its multipseudogene family. Conversation of noncoding regions and chromosomal dispersion pseudogenes. Mol Cell Biol 1985;5:2720 32. 
20. Conboy JG, Chan J, Mohandas N, Kan YW. Multiple protein 4.1 isoforms produced by alternative splicing in human erythroid cells. Proc Natl Acad Sci USA 1988;85:9062-5.

21. Yonemura Y, Endou Y, Nojima N, Kawamura T, Fujita H, Kaji $\mathrm{M}$, et al. A possible role of cytokines in the formation of peritoneal dissemination. Int J Oncol 1997;11:349-58.

22. Taniguchi K, Yonemura Y, Nojima N, Hirono Y, Fushida S, Fujimura $\mathrm{T}$, et al. The relation between the growth patterns of gastric carcinoma and the expression of hepatocyte growth factor receptor (c-met), autocrine motility factor receptor, and urokinase-type plasminogen activator receptor. Cancer 1998;82:211222.

23. Bandou E, Yoneumura Y, Endou Y, Sasaki T, Taniguchi K, Fujita $\mathrm{H}$, et al. Immunohistochemical study of MT-MMP tissue status in gastric cancer and correlation with survival analyzed by univariate and multivarate analysis. Oncol Rep 1998;5:14838.

24. Yamashita K, Azumano I, Mai M, Okada Y. Expression and tissue localization of matrix metalloproteinase 7 (matrilysin) in human gastric carcinomas. Implications for vessel invasion and metastasis. Int J Cancer 1998;79:187-94.

25. Mayer B, Johnson JP, Leitl F, Jauch F, Heiss MM, Achildberg $\mathrm{W}$, et al. E-cadherin expression In primary and metastatic gastric cancer; down-regulation correlates with cellular differentiation and glandular disintegration. Cancer Res 1993;53:1960-5.

26. Yonemura Y. Mechanisms of the formation of peritoneal dissemination. In: Yoneumura Y, editor. Peritoneal dissemination. Kanazawa: Maeda Shoten; 1998. p. 1-46. 